\title{
Character Education Model in Family to Create Good Citizen
}

\author{
Lisna Wati*, Dadang Sundawa \\ Universitas Pendidikan Indonesia \\ Bandung, Indonesia \\ *watilisna.28@gmail.com
}

\begin{abstract}
Character education is an education that teach about human behavior values. Family is first and primary environment for a child because its task is to lay the first basics for child development before they come into broader environment. Thus, the role and function of family become crucial and responsible for child growth and development. This study aims to reveal character education model in family to create good citizen with sub focus comprising character education values, character education model and obstacles in character education. Qualitative approach by using case study method is done in this study. This study use data collection technique with interview, observation, documentation and questionnaire. The result of this study shows that the character values inculcated in family including religious, independent, responsible, sanity, honest, love each other, and low profile. The character education model provide habituation, exemplary, advice, story and law. Parent obstacles in applying character education in family including the influence from outside home environment and parent and children relation which is less close.
\end{abstract}

\section{Keywords-character; family}

\section{INTRODUCTION}

Character education is process to develop in students an awareness as citizen who is dignified, independent and sovereign, has willingness to maintain and defend that independence and sovereignty [1]. Character education is a transformation of life values to be cultivated in one's personality so it become one in that life. Character education comprise three important ideas, namely: 1) process of values transformation, 2) cultivated in personality, 3) become one in behavior [2].

According to a well-known educational figure in Indonesia, Ki Hajar Dewantara, educating demand all natural power existed in child in order they can achieve safety and happiness as human and as society members as high as possible [3]. Civic education should be given attention, because there is no task which is more important than the task to develop citizen who has knowledge, skill and character needed with right commitment toward the values of fundamental and democratic principle. Therefore, those who implement Civic Education learning should develop civic competences which consist of civic knowledge, civic skills, and civic disposition [4].

The character possessed by someone also will give great influence to the group where he or she belong to it, whether it is small group such as family or big group such as society, nation even country. It is similar with statement of Cicero that the model of family building is something done repeatedly and it is constant [5,6]. Parents are the first person who give educational model, guidance and care in family. But in reality, many parents who do not know the good building model given to their children. Even there are some parents who are busy working with the reason that it is for their children future, so they let their children to grow and develop by their own and with school and surrounding environment without parents' guidance.

One of educational sub system which also has crucial role in forming citizen's character is informal education (education in family environment). According to Syarbini that: "Family is primary environment which can shape child disposition." [7]. It means that parents who are primary educator in a family has full responsibility in educating their children at home. Unconsciously, since they were born children had received education from their parents about many things including how to become good children.

Religious values can become a solution in the midst of nation moral decline, violence action, fighting, illegal drugs consumption, and another criminalities, character education emphasizing religious-value dimension become relevant to be applied [8]. Parents are the first teacher for children to ask about small things until big things. From that experience, it can be defined that education acquired by students is a form of guidance which is given and directed by parent. Unconsciously, parents in family life had taught civic values to their children through informal education. Therefore, education in family is very influenced on the process of child's development and character in educational process or after that. Family is first environment for children, through family children will recognize value and norm prevailed in family and society [9].

\section{THEORETICAL STUDY}

\section{A. Definition of Character}

Character has three parts which are interrelated namely moral knowledge, moral feeling and behavior. Good character consist of knowing the good things and desire the good things. Habit in the way of thinking, habit in heart, and habit in action. Those three things are needed to direct a moral life and to shape moral maturity [4]. 
Character refer to a set of attitudes, behaviors, motivation and skills [10]. Character derived from Greek words which means "to mark" and to focus on how to apply civic value on action or behavior. There are some who say that when speaking about character, it is actually speaking about human "behavior" which is based on habitual behavior. But, that habitual behavior derived from first behavior (act) which underlie whether an action is favorable so not doing the same action in the next time. The first action will be strongly influenced by one's "paradigm" or "mindset" [11].

Besides, character is disposition, personality, identity inherent in self which is related to psychic and physic dimension. In micro level, character is (i) quality and quantity of reaction to one self, others, and certain situation, and (ii) disposition, moral and psychological characteristic [12]. The psychological characteristic possessed by individual in personal domain will be developed broader to become social characteristic. Individual's psychological characteristic will give color and motive of group identity which in macro level will become psychological characteristic or nation character. "The character formation of a nation is processed dynamically as a socio-ecological phenomena" [13].

Character education is not new program. It has become part of human life for centuries ago. Indeed, education itself is media to achieve knowledge and wisdom in living the life and to create a good life for humans. Regarding character education, terminology education is said as process to collect good knowledge, attitude and action. Education begins by building awareness, feeling, attention, intention, knowledge, belief and habit formation [14].

The success of character formation is not as easy as we think, but it needs a process and stage to realize it. Therefore, it is important to habituate children where they are, whether in family, school, or community. It is in accordance with Suwarno that education take place in three educational environments, namely in family environment, school environment and community environment [15]. Those three educational environments also introduced by The Father of Education, Ki Hadjar Dewantara as Three Centre of Education.

With the three environments which can be synergy, it is expected that there is no more stigma that school only provide mobility upward, so it is conflicted with education at home which drive traditional values [16]. It is often happens because school often viewed as one component of child education, so most parents usually prefer involvement strategy which consist of activity beyond school system, such as driving their children ability in religious and community organization or supervising their affiliation ability with their peers [17].

As for the basic aim of character education is to make someone to become good and smart. In Islam history, Rosulullah PBUH also assert that his main mission in educating humans is to form good character. The thousands year after that, the main formulation of educational aim remain in similar domain, namely to form good personality in humans [18].

Character education aims to shape and build students' mindset, attitude and behavior in order to become positive individual who has good moral and responsible [19]. In educational context, character education function to shape good identity in students in the sense that students try to realize final attitude, disposition, character, and moral in the form of noble action which is suited with Islamic values so the benchmark of character education has beneficial meaning for all elements.

Character education should not constrained to moral knowledge only but should comprise moral feeling including conscience, self-confidence, emphatic, virtue, self-control, and low profile. Then character education should continue to the most important stage namely moral action. It is important because this stage can motivate people to have good behavior as seen from competence, desire and habit. The building of these moral components is requirement in implementing character education to develop students' moral intelligence [20]. Character education is important for human growth in a whole and should be done earlier. But it doesn't mean that if you cannot provide Character Building basic education, then educational institutions also do not need to provide it. It is important for educational institutions not only attentive to students' need in academic competence, but also to character development so they become graduates who have good character and academic readiness [21].

According to some theories, character values which need to be taught to children include honest, loyal and reliable, respect, love, unselfish and sensitive, generous, brave, love peace, independent, self-discipline, show justice and affection [22]. Furthermore, regarding grand design of character education, the main values which will be developed in formal and informal education are honest, responsible, smart, healthy and clean, care, creative and helpful [23].

\section{B. Family}

Family is a collection of people who live together in the same place and each members feel attachment so they will influence and care each other and interdependent [24]. As expressed by Santrock "family is a system formed by interrelated and interacted parts, and it should be remember that relation never build in one way" [25].

Character education is so important for children, so they can lean it in school and in family. Parent should display good character in family. Family has crucial role in forming individual's character. Each children will be educated by their parent as their first teacher. Value education through family, peers, and mass media is influential to form students' character [26].

\section{Citizen}

What become right for state is become the duty for citizens, whereas what become duty for citizens is become right for state. Therefore, citizens and the state where they live should protect each other. The goal to establish the state is to make humans achieve personal happiness [27]. Furthermore, the goal of state only can be achieved if there is a government which capable to mobilize and direct all people's potential [28].

There are so many human needs, so they cooperate and united. Human's cooperation for the common good have 
generate skill, proficiency, and specialization and job division which is increasingly complex. Therefore, the state should be seen as a service system which require each citizen to complete each other, give and take, exchange service, care about the others' needs, and develop each other responsibly [29].

Good citizens have discipline in religion. That is, they do their duty and do not do what are forbidden [30]. Good citizens means do the religion command and obey the state's law, live in harmony and build harmonious relation with human fellows and live in justice. Actually, moral education in family is the most important thing to be taught so children become good individual and it will help them to become good citizen. It can be supported by the role played by school as formal educational institution by providing civic education, gender education and understanding about plurality [31].

\section{METHOD}

The approach used in this study is qualitative approach, researcher try to understand the meaning which underlie participant behavior, describe complex setting and interaction, identify the types of information and describe phenomena [32].

Whereas case study method, design and model used in this study by using qualitative-naturalistic with limited scope. According to Bodgan and Bikhen, a detailed examination of one setting, or one single subject, or one particular event. The case study model described above is single case study [33].

Single case study design more focus on thorough investigation on a program, event, and activity done by a group of individuals, in which information collected completely by using various procedures of data collection with time limit. Besides, case study design is used to explore certain process, activity, and events [34]

Regarding the selection of participant or research of study, Miles and Huberman reveal that some criteria which can be used, namely: setting, actors, events and process [35]. In accord with the forms of data collected in this study, the sources of data in this study comprise human, object and event. Human in qualitative study is source of data and has status as informant who give information about phenomena or problem in accord with focus of study. In determining technique to obtain clear and qualified information when answering study problems, probability sampling technique is used [36].

Researcher use subject or object as analysis unit based on need and consider that analysis unit can be representative to obtain the result of study. The informants used in this study is Aceh community or family. In total, the subjects which will be taken by researcher as participant in this study are 9 families. Based on substantive theory that this study is purposively conducted in Ujong Patihan Village, Kuala Kabu Paten Nagan Raga Sub-district, Aceh Province as the site of study.

The objects are studied through direct observation, in depth interview, and documentation.

\section{RESUlt AND DisCUSSION}

\section{A. Result}

Character education in family can be interpreted as a step from parents to their children in inculcating character and religious values which are important in religion and in daily life to do the obligation as Muslim. To be independent, children is habituated to wash dishes and tidy up their bedroom by themselves. Children are given responsibility to do their duty at home and in the environment where they live. Children also should clean their house and their environment, honest in each action they do in daily life, love family members and the others people around them and show low profile and not being arrogant when making friends.

In applying character value in family, parents want their children to become good, honest, independent, love peace, and responsible for their duty. Good character initiated from how parent educate their children. The character value always influence children behavior in family. Religious value can be inculcated in children since early age by instructing them to take pray punctually and do fasting. The character value inculcated in family is very important for children behavior in order to become honest, independent, and not easily rely on others people in accomplishing the task given.

The model of character education in family to shape good moral by applying the methods of habit, role model, advise, motivation, story and punishment. From those methods there is similarity and difference of method applied in each family. Each family differ in applying character method because the conditions dialed with are different. Through character method, children capable to understand character values which are positive/noble in daily behavior. Parent's behavior also become example of character education model in family by showing politeness, honesty and good behavior in front of children.

Each parent always apply character education method in family. The method given by parent to their children is role model method. Parent behavior can be imitated easily by children. The method of habituation which is given to children since early age include habituate children to weak up in the morning, say greeting when they will go, and to throw the garbage in its place. By applying the method of character education in family, it is expected that children will become better. Parent give good direction to their children through role model.

Family is primary education for children before them familiar with outside world. They always give role model to their children. Parents always give good model in their words and behavior and give good guidance to their children in order to be always close to Allah. Parents always try to spend their time for their children no matter how busy they are with their work. Children's good character is strongly influenced by how family educate them at home.

However, there are many factors which become parents' obstacle in educating their children. Beside at home, character education also influenced by environment outside home. Parents sometimes unable to monitor their children when they 
are outside. Therefore, parent-children relation is needed so parents can monitor children activity.

\section{B. Discussion}

According to some theories, the character values which need to be taught to children include being honest, loyal, reliable, respect, love, unselfish and sensitive, generous, brave, love peace, independent, self-discipline, have justice and affection [22]. Good moral and good character have many similarities in quality [37]. Besides, character is disposition, personality and identity inherent in one self-relate to psychic and physic. In micro level, character is (i) quality and quantity of reaction to one self, another people, and certain situation, and (ii) disposition, moral and psychology characteristic [12].

Character values that parent inculcate to their children since early childhood, will form good character in children in which they are not easily influenced by bad environment. Each family always habituate character values to their children both in behaving toward their peers and community. Parents habituate good behavior in front of their children, and children will imitate their parent's behavior which become role model for them. Good character is given through children habituation in family. Character values always habituate good behavior to children. Those values are honest, independent, discipline, responsible, love peace and tolerate.

Every family in this world who pay attention to character education should identity character values which will become behavior pillar for children in family. Those character values can be derived from religious tenets, philosophy and nation culture, or norms and values of local wisdom prevailed in society [7]. Actually, character education not only tell what is right and what is wrong, but include habituation process of good behavior so good character will be formed [38]. Family play important role in the process of character formation containing values. Wardi express that: "before recognizing norms and values prevailed in society, children for the first time absorb norms and values prevailed in their family. These norms and values become part of their personality". By absorbing the values prevailed in family, children will understand their own role in family [39].

The specific aim of character education in family is to direct and guide children in order to have good character or noble moral. As for general aim of character education is to prepare children to live optimally and they can be beneficial for themselves, their family, their community even their religion and nation [7]

The model of character education in family aims to create noble moral in family. The methods used in character education in family among others are internalization, role model, habituation, playing, storytelling and advice. Method as a way to inculcate good character in children. Parents should give good model in family. Good children will maintain good attitude toward the others. Parents' role model will give good model of behavior in family which children see every day. Good habituation done by parents in family will habituate children to show honest, responsible and polite attitudes. To apply the model of character education in family, parents always use educational system approach which comprise goal, material, method, program and evaluation.

\section{CONCLUSION}

Character values which are inculcated by parents in family are religious value, honest, independent, responsible and discipline. Creating good character by inculcating character values in family life is an attitude which is done continuously in family to form good character.

The model of character education in family can be done through aim, material, method, program and evaluation. The method of character education in family is done through internalization method, role model method, habituation method, playing method, story method and parents give advice to their children. Parent give advice and motivation to their children by attitude and behavior of habituation. Parents educate children with good values by giving advice and good model. Besides, another models of character education include role model, story and law. The obstacles faced by parents in applying character education in family are environment outside home and parent-children relation which is less close.

\section{REFERENCES}

[1] Zamroni, Strategi dan Model Implementasi Pendidikan Karakter di Sekolah, Yogyakarta: UNY Press, 2011.

[2] D. Kesuma, Pendidikan Karakter, Bandung: PT Remaja Rosdakarya, 2011.

[3] M. Sukardjo, and K. Ukin, Landasan Pendidikan Konsep dan Aplikasinya, Jakarta: PT Raja Grafindo Persada, 2012.

[4] M. Branson, The Role Civic Education, A Fortcoming Education Policy Task Force position, Paper from the Communitarian Network, 1998.

[5] T. Lickona, Bagaimana Sekolah dapat Memberikan Pendidikan tentang Sikap Hormat dan Tanggung Jawab, Jakarta: Remaja Rosdakarya, 2012.

[6] E.W. Syaodi, Peran Bimbingan Guru Pengasuh Orang Tua, Interaksi Teman Sebaya Terhadap Perkembangan Prilaku Sosial Anak, Bandung: PPS-IKIP, 1999.

[7] A. Syarbini, Buku Pintar Pendidikan Karakter: Panduan Lengkap Mendidik Karakter Anak di Sekolah, Madrasah, dan Rumah, Jakarta: As@-Prima Pustaka, 2012.

[8] Wahyu, Masalah dan Usaha Membangun Karakter Bangsa, Bandung: Widya Aksara Pers, 2011.

[9] N. Purwanto, Psikologi Pendidikan, Bandung: Remaja Rosdakarya, 2006.

[10] Aqib, Zainal, and Sujak, Panduan dan Aplikasi Pendidikan Karakter, Gaung Persada Press, 2011.

[11] Y. Kardiman, "Karakter Adalah Akar Masalah Bangsa Kita", Jurnal Media Komunikasi, vol. 12, No. 2, Agustus 2013

[12] B. Nurgiyantoro, "Wayang dan Pengembangan Karakter Bangsa”, Jurnal JOUSA, Vol. 1, No. 4, pp. 99-109, Oktober 2014.

[13] A. Gufron, "Integrasi Nilai-Nilai Karakter Bangsa pada Kegiatan Pembelajaran", Cakrawala Pendidikan, Jurnal Ilmiah Pendidikan, pp. 13-24, May 2010.

[14] F. Rokhman, M. Hum, and A. Syaifudin, "Character Education For Golden Generation 2045 ( National Character Building for Indonesian Golden Years)", Procedia - Social and Behavioral Sciences, 141, 11611165,2014

[15] H. Suwarno, Administrasi Pemerintahan dalam Pembangunan Nasional, Jakarta: PT. Gunung Agung, 1985.

[16] S. Roubeni. "If We Can't Do It, Our Children Will Do It One Day": A Qualitative Study of West African Immigrant Parents' Losses and 
Educational Aspirations for Their Children", American Educational Research Journal, Aera Jurnal, vol. 52, no. 2, pp. 275-305, 2015.

[17] L. Poza, M.D. Brooks, and G. Valdes, "Entre Familia: Immigrant Parents Strategies For Involvement in Children's Schooling", School Community Journal, vol. 24, pp. 119-148, 2014.

[18] M. Abdullah, Pendidikan Karakter Perspektif Islam, Bandung: Rosda, 1998.

[19] A.Z. Fitri, Pendidikan Karakter Berbesis Nilai dan Etika Di Sekolah, Yogyakarta: PT Ar-Ruzz Media, 2012.

[20] M. Magda, and R. Patriana, "The Significance of Environmental Contents in Character Education for Quality of Life", Procedia-Social and Behavioral Sciences, 222, pp. 244-252, 2016.

[21] S.A. Kamaruddin, Character Education and Students Social Behavior, vol. 6, pp. 223-230, 2012.

[22] M. Muslich, Pendidikan Karakter Menjawab Tantangan Krisis Multidimensional, Jakarta: Bumi Aksara, 2011.

[23] M. Samani, and Hariyanto, Konsep dan Model Pendidikan Karakter, Bandung: PT Remaja Rosdakarya, 2012.

[24] M. Shochib, Pola Asuh Orang Tua, dalam Membantu Anak Mengembangkan Disiplin Diri, Jakarta: PT. Rineka Cipta, 2000.

[25] J.W. Santrock, Remaja: Edisi 11 Jilid 2, Jakarta: Erlangga, 2007.

[26] S. Wening, "Pembentukan Karakter Bangsa Melalui Pendidikan Nilai", Jurnal Pendidikan Karakter, No. 1, pp. 55-66, february 2012.

[27] Wirnano, Pendidikan Kewarganegaraan: dari Sosiologis menuju Yuridis, Bandung: Alfabeta, 2009.
[28] R. Surbakti, Memahami Ilmu Politik, Jakarta: PT.Gramedia Widiasarana, 1999

[29] J.H. Rapar, Filsafat Politik Plato, Aristoteles, Augustinus, dan Machiavelli, Jakarta: PT. RajaGrafindo Persada, 2002.

[30] I.C. Hermawan, "Esensi Pendidikan Politik dan Kaitannya Dengan Pembentukkan Warga Negara yang Baik", vol. 15, No. 29, JulyDecember 2009.

[31] L.C. McClain, "The Domain of Civi Virtue in a Good Society: Families, shools, and Sex Equality", Fordham Law Review, vol. 69, no. 5, pp. 1617-1666, 2001.

[32] Mardiyah, Kepemimpinan Kiai dalam Memelihara Budaya Organisasi, Malang: Aditya Media Publishing, 2012.

[33] Bodgan and Biklen, Qualitative Research for An Introduction the Theory and Method, London, 1982.

[34] J.W. Creswell, Research Design: Pendekatan Kualitatif, Kuantitatif, dan Campuran, Yogyakarta: Pusataka Pelajar, 2009.

[35] B.M. Milles, and A.M. Huberman Analisis Data Kualitatif: Buku Sumber Tentang Metode-Metode Baru, Jakarta: PT Gramedia, 2007.

[36] Sugiyono, Memahami Penelitian Kualitatif, Bandung: alfabeta, 2005.

[37] S.O. Nur, "A Study of Moral Education and its Relationship with Character Education", vol. 5, no. 2, pp. 353-358, 2014.

[38] R. Lisrtyarti. Pendidikan Karakter dalam Metode Akrtif, Inovatif dan Kreatif, Jakarta: Erlangga, 2012.

[39] M. Wardi, "Penerapan Nilai Pendidikan Agama Islam Dalam Perubahan Sosial Remaja”, vol. 7, no. 1, pp. 31-44, 2012. 